\title{
Land Use in Watersheds of the Venezuelan Andes: a Comparative Analysis
}

\author{
J. D. ALLAN, ${ }^{+\dagger}$ A. J. BRENNER, $†$ J. ERAZO, ${ }^{*}$ L. FERNANDEZ, ${ }^{*}$ A. S. FLECKER, $\ddagger$ \\ D. L. KARWAN, ${ }^{*}$ SAMUEL SEGNINI, $₫$ AND D. C. TAPHORN** \\ *School of Natural Resources and Environment, The University of Michigan, Ann Arbor, MI 48109-1115, U.S.A. \\ †Pacific Meridian, 455 East Eisenhower Parkway, Ann Arbor, MI 48108, U.S.A. \\ ‡Department of Ecology and Evolutionary Biology, Cornell University, Ithaca, NY 14853, U.S.A. \\ §Departamento de Biología, Universidad de Los Andes, Mérida 5251, Venezuela \\ **Museo de Zoologia, Universidad Nacional Experimental de los Llanos Occidentales Ezequiel Zamora, \\ Guanare, Estado Portuguesa 3310, Venezuela
}

\begin{abstract}
The influence of deforestation on tropical watersheds bas received limited study. We compared seven catchments in the Venezuelan Andes to examine variation in the relative extent of forested versus disturbed land and the potential consequences of changing land use on river ecosystems. These watersheds formed a northeast (Río Acarigua) to soutbwest (Río Bumbun) transect and exbibited a gradient in readily observable buman settlement and disturbance. Overall, forest cover increased and agriculture and pasture land decreased from the Acarigua to the Bumbun. Human building density and road density showed a parallel trend. Catchments varied in intrinsic characteristics as well. Catchments to the northeast originated at lower elevations and had wider, flatter valleys in the lowest piedmont zone, compared with rivers to the southwest. All seven catchments had broadly similar forest cover at approximately 50-60\% within the lowest (200-800 m) elevation zone, but they exbibited a strong gradient in the amount of forested versus disturbed land in zones at 800-1400 $\mathrm{m}$ and 1400-2600 m. Although the number of buildings was greatest in the 200-to 800-m zone, building density was greater in the 800- to 1400-m zone for the more disturbed catchments, possibly reflecting the areas suitable for coffee production. Land-use change within these catchments is likely to alter hydrology, sediment transport, and habitat conditions within river systems, with adverse consequences for aquatic biodiversity.
\end{abstract}

Uso del Suelo en Cuencas de los Andes Venezolanos: un Análisis Comparativo

Resumen: La influencia de la deforestación en las cuencas tropicales ha recibido una atención limitada en cuanto a su estudio. Comparamos siete cuencas de captación en los Andes Venezolanos para examinar la variación en la extensión relativa del bosque, contra suelos perturbados y las consecuencias potenciales del cambio en el uso del suelo en ecosistemas de ríos. Estas cuencas formaron un transecto de noreste (Río Acarigua) a suroeste (Río Bumbun) y exbibió un gradiente de asentamientos humanos y perturbación fácilmente perceptible. En general, la cobertura forestal incrementó y la agricultura y el pastoreo disminuyeron del Acarigua al Bumbun. La densidad de las construcciones bumanas y de carreteras mostraron tendencias paralelas. Las cuencas de captación variaron en características intrínsecas también. Las cuencas de captación ubicadas al noreste estuvieron originadas a elevaciones más bajas y tuvieron valles más amplios y planos en la zona más baja comparadas con las de los ríos del suroeste. Las siete captaciones fueron similares de manera general en aproximadamente un 50-60\% de la cobertura forestal dentro de la zona más baja de elevación (200-800 m), pero exbibieron un fuerte gradiente en la cantidad de suelo arbolado contra tierras perturbadas en zonas de 800-1400 m y 1400-2600 m. A pesar de que el número de edificios fue mayor en la zona de 200 a $800 \mathrm{~m}$, la densidad de edificios fue mayor en la zona de 800 a 1400 m para las cuencas de captación más perturbadas. Esto posiblemente refleje las áreas viables para la producción de café. Es probable que el cambio de uso del suelo dentro de estas cuencas de captación altere la hidrología, el transporte de sedimentos y las condiciones del hábitat dentro de los sistemas del río, con consecuencias adversas para la biodiversidad acuática.

†† email dallan@umich.edu

Paper submitted July 12, 2000; revised manuscript accepted June 13, 2001. 


\section{Introduction}

Despite continuing debate over actual rates of clearance of tropical forests (Melillo et al. 1985; Lanly 1995; Whitmore 1997), it is clear that vast areas of previously forested landscapes have been greatly altered. Most reports, referring to the 1970 s to early 1980 s, put the average yearly deforestation rate for tropical South America near 0.6\% (Lanly 1995); Whitmore's (1997) revised Food and Agriculture Organization estimate for 1981-1990 is $0.81 \%$. Numbers are uncertain for many reasons, including how deforestation is defined, the limitations of Landsat imagery in detecting subcanopy disturbance (Nepstad et al. 1999), and the considerable spatial and temporal variation in forest clearance. With close to half of the world's tropical forests now converted, and with some indications that deforestation rates might be increasing (Whitmore $\&$ Sayer 1992), much concern has arisen over the consequences for biodiversity loss and global carbon flux.

Conversion of forested land to agriculture and pasture will adversely affect river ecosystems. Cross-catchment comparisons within the temperate zone show strong correlations between a high percentage of agricultural land use and declines in water quality (Omernik 1977; Johnson et al. 1997; Castillo et al. 2000). Metrics of habitat quality and biological integrity also decline with reductions in natural land cover (Richards et al. 1996; Roth et al. 1996). Changes in hydrologic regime are a well-established consequence of land conversion. Total runoff and magnitude of peakflow increase when forest is replaced with cropland, primarily due to reductions in evapotranspiration (Bosch \& Hewlett 1982; Bruijnzeel \& Bremmer 1989). The annual height of the Amazon's flood crest at Iquitos increased over the period 19621978, despite no significant change in precipitation, which Gentry and Lopez-Parodi (1980) attributed to deforestation within the Amazon basin. Dry-season flows commonly although not invariably decrease when forest is converted to crops or pasture (Bruijnzeel 1989). Changes in flow regime can negatively affect many aspects of river ecosystems, such as habitat, spawning opportunities for fishes, and food-web interactions (Poff et al. 1997). In rivers of the Venezuelan piedmont, where our study was situated, complex food-web interactions involving sediment-feeding fishes and the amount of deposited sediments, which likely is related to forest clearance and discharge, affect many species in the community (Flecker 1996).

The great diversity of fishes in Venezuelan piedmont rivers includes numerous species of importance to commercial and subsistence fishing. Many of these fishes undergo long migrations between the llanos, where they feed and reproduce during the wet season, and rivers of the Andean piedmont, their dry-season refuge. Declines in a number of species, including the abundant coporo
(Prochilodus mariae), appear to have multiple causes (Winemiller et al. 1996; Barbarino et al. 1998), including reduced dry-season flows attributed to deforestation. As the land area within river valleys becomes more settled and transformed, the state of the rivers declines and valued ecosystem goods and services are lost.

Roads and infrastructure are well-established associates of tropical deforestation (Fearnside 1980). In Costa Rica, where forest loss over the interval 1940-1983 was well documented, forest clearing was strongly correlated with proximity to roads, and cumulative road length more than doubled from 1967 to 1977 (Sader \& Joyce 1988). Loss of forest in northern Sierra de Los Tuxtlas, southeast Mexico, began first with clearing of low, flat areas and opening of new roads (Dirzo \& Garcia 1990). As deforestation continued, large tracts of forest remained only in the highest and least accessible areas. Population pressure is also a common correlate of deforestation (e.g., Vina \& Cavelier 1999). As several authors have pointed out (Rudel \& Roper 1996; Bawa \& Dayanandan 1997), however, underlying socioeconomic mechanisms are many, varied, and complex.

We examined land use and cover within a series of river valleys in a northeastern-to-southwestern transect along the southern slope of the Venezuelan Andes. Our objectives were to determine the extent of forested versus disturbed land among a series of catchments that varied in their apparent level of human alteration. We hypothesized that the extent of human disturbance, assessed from satellite imagery, would vary among seven study catchments in relation to human population and settlement patterns. The upper regions of these catchments, generally less accessible, were expected to be less disturbed. Despite widespread concern about the effects of forest loss on terrestrial ecosystems, relatively few formal analyses have been undertaken to examine the consequences for aquatic habitats.

\section{Methods}

\section{Study Region}

Our region of study was along the southern slope of the Andes, where a series of rivers originating at elevations from over $1200 \mathrm{~m}$ to nearly $4000 \mathrm{~m}$ drain toward the interior of Venezuela. Gradients initially are steep, but become more gradual in the lower piedmont region below approximately $800 \mathrm{~m}$. Rivers leave the foothills at approximately $200 \mathrm{~m}$, where they begin their meandering traverse of the llanos until reaching the Río Apure, a major left-bank tributary of the Orinoco River. The paved Llano Alto Highway demarcates the boundary between piedmont and llanos and connects a series of cities and small towns from Acarigua in the northeast to Guanare 
and Barinas toward the southwest. Our study was confined to the region above the Llano Alto Highway.

Field visits to multiple sites strongly indicated that the seven rivers and their catchments represented a gradient in human settlement and disturbance from the northeast (Río Acarigua) to the southwest (Río Bumbun), and that headwaters were less accessible and presumably less disturbed. The elevational gradient presented marked changes in temperature, precipitation, and vegetation (Table 1). A zone from 200 to $800 \mathrm{~m}$ included the lower piedmont, approximately between the llanos and the point where the Andean slope steepens. It also marked the approximate upper limit of easy road access and most evident human activity. Originally covered by dry deciduous forest, much of this region has been cleared. Present land use includes some sugar cane and tobacco plantations where the piedmont meets the llanos; crops of banana, cassava, and maize; and some coffee and citrus fruit. Extensive cattle pastures were found on the most deteriorated lands. We found scattered remnants of gallery forest along river courses and individual trees scattered through pastures. In some areas (Río Morador), tree plantations of Eucalyptus, Pinus, and teak are grown for pulp. Roads were extensive, although they varied as to gravel or asphalt.

In the most disturbed catchments, the zone above $800 \mathrm{~m}$ appeared substantially affected by human presence, but vehicle access was limited and settlements were small and dispersed. In contrast, in the least-disturbed catchments we encountered mostly intact primary forest above $800 \mathrm{~m}$, and in the Bumbun valley no footpaths extended above this elevation. The Siniguis and Canagua, two catchments where we conducted detailed field research, had settlements of as many as 10 families at 1000-1400 m. Abandoned hillslopes in the Siniguis valley, covered by dense stands of bracken fern, were indicative of prior settlement. Above approximately 1400-1600 m, human settlement was sparse, especially in the Canagua, Siniguis, and Bumbun catchments, where the gradient is steep and no habitations occurred (personal observations). Above 2600-3000 m, where scrub forest has been replaced by paramo, a few scattered habitations were found, and cattle and mules grazed in the open meadows.

\section{Data Sources}

Land-cover data were derived from two adjacent Landsat 5 thematic mapper (TM) satellite images dated $13 \mathrm{Au}$ gust 1996 (row 51, path X). The images were classified according to a guided classification scheme (Imagine 8.3, ERDAS, Atlanta, Georgia), with combined unsupervised and supervised classification techniques. Initially, an unsupervised (ISODATA) routine was run on Landsat bands 1-5 and 7, which clustered the image into 20 classes. These classes were visually analyzed, and those corresponding to clouds, land surfaces under cloud shadows, and shadows caused by the terrain (about 15-20\% of the image area) were removed from the image. The remaining image area was then clustered into 60 classes by a second ISODATA routine. Clusters were labeled to specific land-cover classes, and signatures of the labeled clusters were used as the basis for a supervised maximumlikelihood classification of the whole study area. This resulted in a land-cover map of nine classes: forest, grassland, agriculture, urban, barren, paramo, water, cloud, and no data. Field visits to over 100 selected sites in February 1998 confirmed the accuracy of this classification. We analyzed data with Arcview GIS 3.2 and Arcview Spatial Analyst (ESRI, Redlands, California). When calculating distance, density, and proximity, we converted digitized vector coverages to GRID (raster) files with 30-m resolution to ensure compatibility of raster land-cover data.

We obtained additional layers of digital data by digitizing 1:100,000-scale topographic maps produced by the Direccion de Cartografia Nacional de Venezuela from 1960 aerial photography (dates are somewhat later for the upper reaches of the Acarigua catchment [1964] and for the Morador and Las Marias catchments [1967]). Field-classification of these maps took place in the early 1970s, except for the Bumbun (1963). These digitized layers included a river layer (classified into main stem, permanent tributaries, intermittent streams), a road layer (classified into paved roads, unpaved roads, and footpaths), elevation contours (200-m intervals at low elevations, 400-m intervals above $1000 \mathrm{~m}$ ), and buildings (houses, schools, and churches).

\section{Data Analysis and Hypotheses}

After separate investigation of agricultural land and grassland, we elected to combine these as a single measure of disturbed land. We hypothesized that the extent of disturbed land would correlate with the disturbance gradient inferred from field observations (greatest in the northeast and at low elevations) and with mapped measures of building and road density. Catchments were divided into four elevation zones (200-800, 800-1400, 1400-2600, and $>2600 \mathrm{~m}$ ) (Table 1 ). Because riparian (streamside) land may be less disturbed than the overall catchment, and because it is considered important to stream health (Allan 1995), we delineated riparian buffers of $100 \mathrm{~m}$ on each side of the rivers to assess land use along river margins. Our analysis included the main stems and permanent tributaries of rivers, but excluded streams with seasonally intermittent flow. We did not examine riparian buffers in the zone above $2600 \mathrm{~m}$, because most of this area was above treeline. To determine whether forest clearing was influenced by the presence of roads, we examined land use within $100 \mathrm{~m}$-wide sequential buffers, delineated on each side of roads and extending laterally to a distance of approximately $4 \mathrm{~km}$. Our rationale was that if deforestation is influenced 
Table 1. The elevational gradient of climate and vegetation in the region of the study watersheds, based on Reaud-Thomas (1989) and personal observations.

\begin{tabular}{lccc}
\hline Elevation zone $(\mathrm{m})$ & Temperature $\left({ }^{\circ} \mathrm{C}\right)$ & Precipitation $(\mathrm{mm})$ & Vegetation description \\
\hline $200-800$ & $25-30$ & $1500-2500$, well-demarcated dry season & $\begin{array}{c}\text { originally dry deciduous forest; now } \\
\text { largely mixed crops, pasture, and } \\
\text { limited silviculture } \\
\text { transitional to wet evergreen low montane } \\
\text { forest; coffee, pasture, limited crops } \\
\text { montane evergreen forest, grading into } \\
\text { cloud forest, with little or no agricultural } \\
\text { activity }\end{array}$ \\
$1400-2600$ & $17-27$ & $2000-3000$ & $600-1000$, seasonality less pro-nounced \\
& $8-17$ & $<600$ & $\begin{array}{c}\text { scrub forest, grading into Paramo } \\
\text { (grasses, Espeletia) above } 3000 \text { m; } \\
\text { some grazing by cattle and mules }\end{array}$ \\
\hline
\end{tabular}

largely by accessibility, then progressively less-disturbed land should be observed as one moves away from roads. We examined buffers along all roads within the 200- to 800-m elevation zone, because this zone showed the greatest reduction in forest cover. The Acarigua site was excluded due to incomplete image coverage.

We evaluated human presence within each catchment based on the density of buildings (primarily houses, as a proxy for human population) and roads, to test our expectation that catchments to the northeast, such as Acarigua and El Morador, were most influenced by human presence and catchments to the southwest, including the Bumbun, Siniguis, and Canagua, were least affected. We examined relationships among road density, building density, and percent disturbed land by entire catchment and by elevation zone to test the expectation that extent of disturbed land would correlate with measures of access and human population. We separately examined the relationship between roads and roads plus footpaths to examine whether both were effective predictors.

All estimates were based on the portion of each catchment not obscured by clouds (12\% of the Acarigua, $13 \%$ of the Morador, negligible for other catchments). In addition, the two satellite scenes did not provide complete coverage of the delineated Acarigua catchment (15\% was excluded along the eastern boundary). The missing area included the lowest region of the watershed, which was mostly urban and disturbed.

\section{Results}

\section{Catchment Characteristics}

The seven study catchments differed in total area and also in the area included in each elevation zone (Table 2 ). The three catchments to the southwest originated in the paramo within the Parque Nacional Sierra Nevada (established in 1952), whereas the remaining four catchments had lower origins. The Acarigua was the largest catchment and, among the more disturbed catchments, had more area at higher elevations. Las Marias and La Yuca originated at comparatively lower elevations and had more of their area within the 200- to $800-\mathrm{m}$ pied-

Table 2. Catchment area $\left(\mathrm{km}^{2}\right)$ within each of four elevation zones and lateral valley slopes (degrees) within the piedmont section for the seven Andean study catchments. ${ }^{a}$

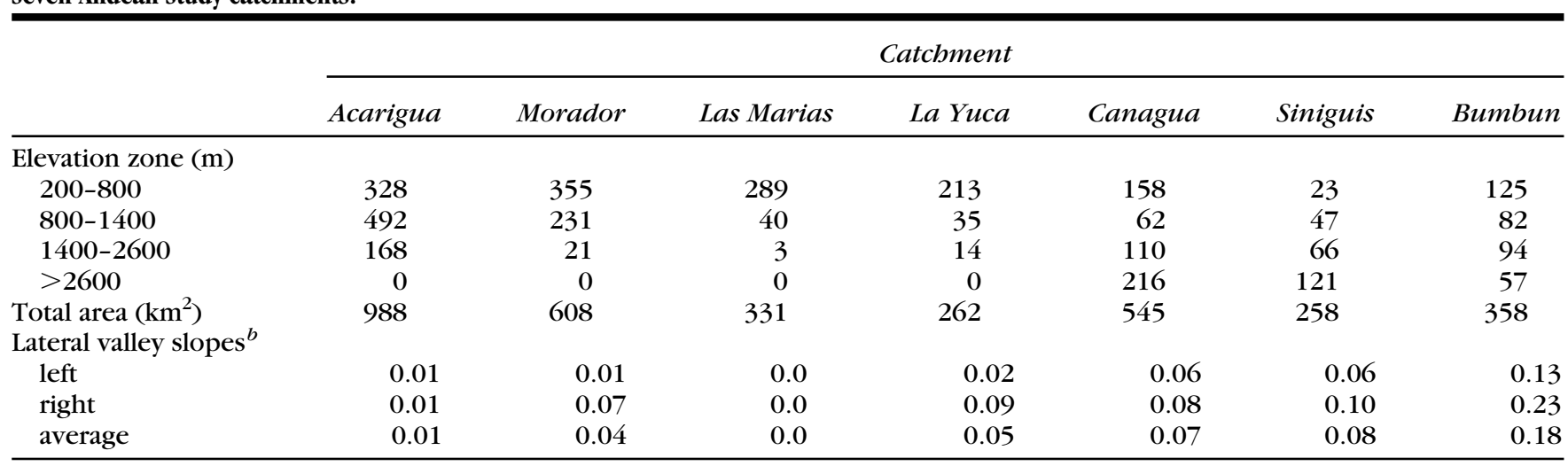

${ }^{a}$ Note the larger area of the Acarigua catchment and the greater area at bigh elevation in the Canagua, Siniguis, and Bumbun catchments.

${ }^{b}$ Estimated from a 4-km cross-section centered on the river within the piedmont or lowest elevation zone and derived from 1:100,000 mapped contours. The cross sections from the Acarigua to Las Marias valleys are relatively flat, and the slopes of the Canagua to Bumbun valleys are laterally steep. 
mont zone. These catchments also differed in the crosssectional shape of their lower valleys. The piedmont valleys of the catchments to the northeast had relatively wide, flat valleys (Table 2 ), showing virtually no slope within a 4-km cross-section. Lateral valley slopes were steeper for the catchments to the southwest and reached a maximum of 0.18 for the Bumbun.

\section{Land Use}

Evaluated at the scale of entire catchments, the extent of forested land increased from the Acarigua toward the Bumbun, in accordance with the expected disturbance gradient. Values ranged from 50\% (Acarigua) to $80 \%$ (Bumbun) forested. Field observations were consistent with these trends, but areas classified as forest may have included mixed forest and crop associations and tree plantations. The latter were encountered frequently in the Acarigua and Morador catchments, suggesting that our estimate of forest area in the most altered catchments included secondary forest. The extent of disturbed land (agricultural + pasture) hovered near $40 \%$ for the Acarigua to La Yuca catchments and then declined to values near $10 \%$ for the Canagua to Bumbun catchments.

Urban land varied from a low of 2-3\% (Bumbun, Canagua, and Siniguis catchments) to a high of $11 \%$ (Acarigua). Paramo comprised approximately $15 \%$ of the area of the Canagua and Sinigis catchments, consistent with their origin at high elevations. We estimated less paramo in the Bumbun due to a lower point of origin than the Canagua and Siniguis.

When analyzed by elevation zone, land-cover trends showed substantial differences among the four elevation zones and across catchments (Fig. 1). Within the 200- to 800-m elevation zone, catchments differed little in estimates of the relative amount of forested and disturbed land. In contrast, the trend toward increasing forest and decreasing disturbed area from the Acarigua to the Bumbun was strongly supported by separate examination of the 800to $1400-\mathrm{m}$ and 1400 - to $2600-\mathrm{m}$ zones. Only the Canagua, Siniguis, and Bumbun extended into the $>2600-\mathrm{m}$ zone, and most of this area was not forested. The Bumbun valley had more forest than paramo in the $>2600-\mathrm{m}$ zone com-
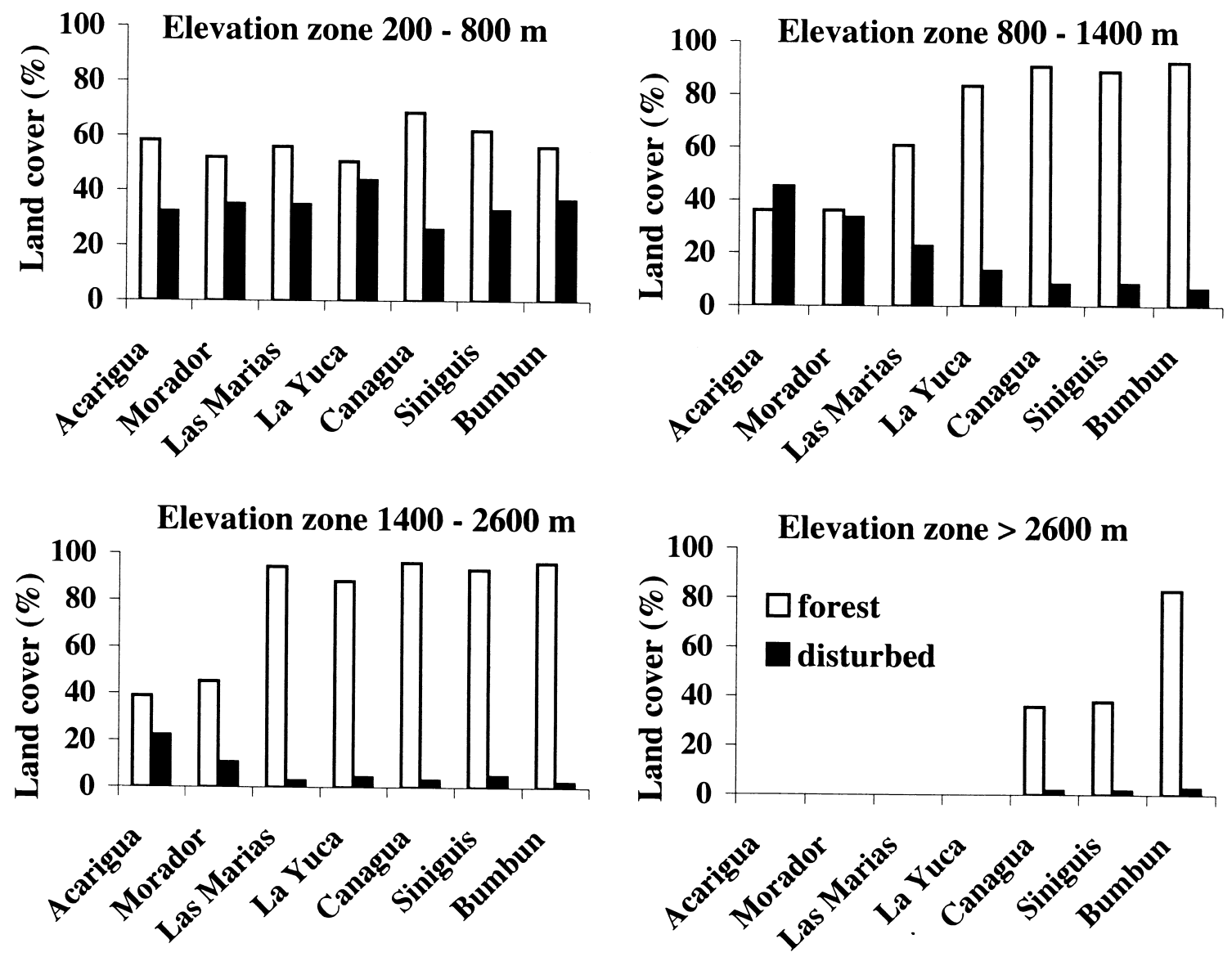

Figure 1. Comparison of land cover and use in four elevation zones across seven Andean catchments. The category "disturbed land" combines areas classified as agriculture and pasture. Estimates exclude portions of the image obscured by cloud and portions of the Acarigua catchment not included in images analyzed. 

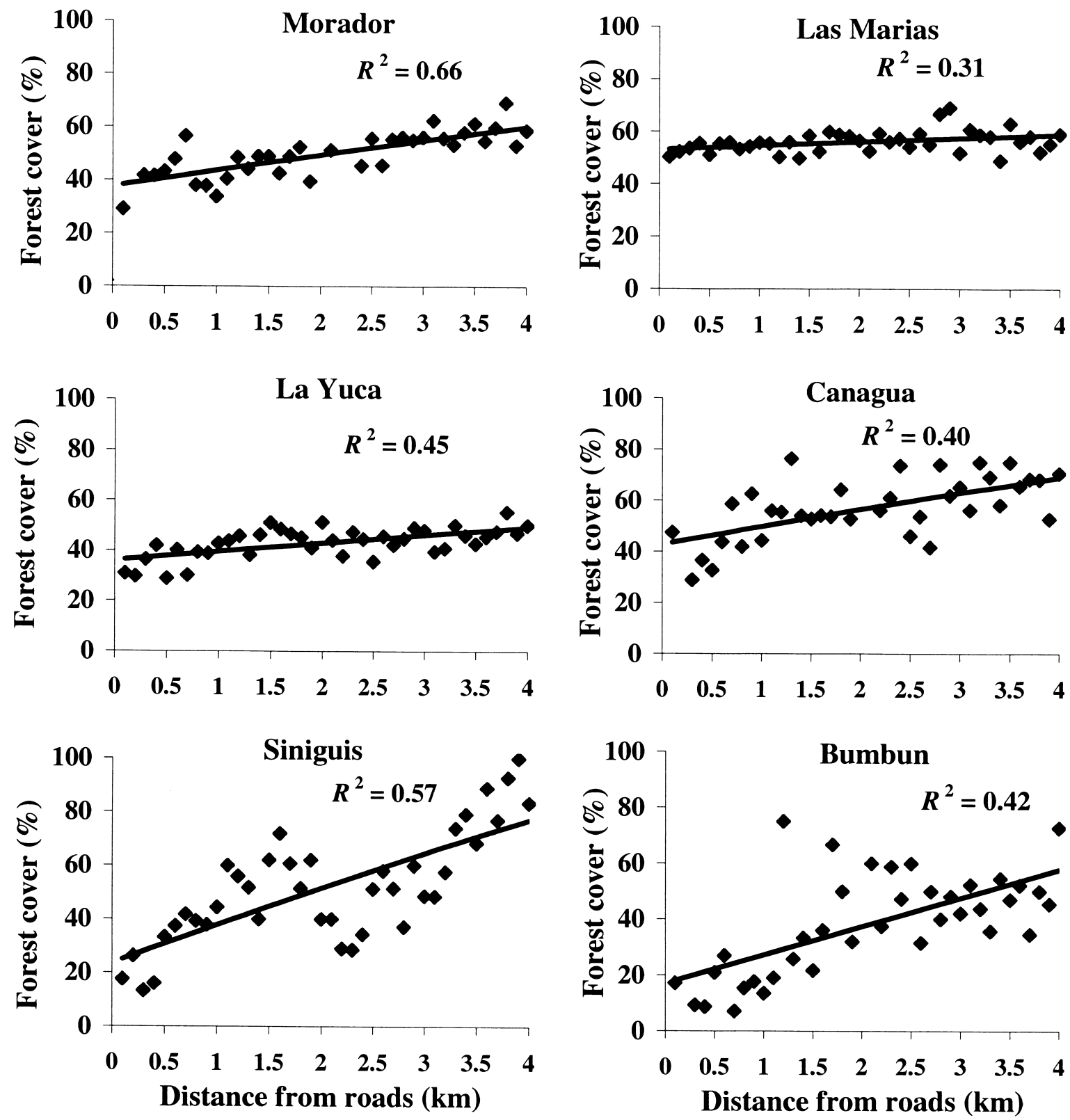

Figure 2. Percent forested land within successive 100-m buffers that extended laterally from roads within the 200- to 800-m elevation zone. The Acarigua catchment was omitted because of some missing data within this elevation zone.

pared with the Siniguis and Canagua, because it had less land area at higher elevations.

The amount of riparian forest within $100 \mathrm{~m}$ of the river exhibited some differences among catchments and with elevation. For five of the seven catchments (Las Marias southwest to Bumbun), the extent of riparian forest was markedly less - in the vicinity of 50-60\% - in the lowest region of the piedmont, than in the two higherelevation zones. In the Acarigua catchment, the percent forest within the 100-m buffer was similar (50-58\%) across elevation zones. Comparing forest area within the entire catchment area with that within the $100-\mathrm{m}$ riparian buff- ers by elevation zone revealed that, for six of the seven catchments, the values for percent forest were similar. For the most part, the amount of forest cover was similar within riparian buffers as it was throughout the catchment. Somewhat surprisingly, in the Morador catchment, more of the riparian area was forested at lower than at higher elevations. The lower piedmont of Morador contained a number of tree plantations, and this may be responsible in part for the reverse trend.

Although there was little evidence that extent of forest was affected by proximity to rivers (i.e., retained in riparian areas), an association between loss of forest and 
proximity to roads was evident in the $200-$ to $800-\mathrm{m}$ zone. In the six catchments examined (Acarigua site excluded due to incomplete image coverage), the percentage of forested land increased as successive $100-\mathrm{m}$ increments were examined laterally away from roads, indicating a clear effect of accessibility on deforestation (Fig. 2). The trend in the Las Marias catchment was barely detectable, whereas in the remaining catchments the percent forest increased by a substantial fraction with distance away from roads.

\section{Human Settlement}

Total numbers of buildings, an indicator of human populations in the catchments as of approximately 1960, decreased steadily across catchments in accord with the anticipated gradient in human disturbance: Acarigua, 1779; Morador, 743; Las Marias, 324; La Yuca, 89; Canagua, 86; Siniguis, 43; Bumbun, 8 . When these numbers were expressed per square kilometer and by elevation zone, two trends were evident (Fig. 3). As expected, building density declined steadily from Río Acarigua to the Bumbun. In addition, it was evident that the density of buildings was greatest in the 800 - to $1400-\mathrm{m}$ elevation zone, presumably because this area is best suited for coffee. The two higher elevation zones were more sparsely settled.

We converted estimates of building density to population density based on an average number per household of six (Baker \& Sanders 1972). The highest densities so estimated were approximately $10-13$ people $/ \mathrm{km}^{2}$ for the Acarigua, Morador, and Las Marias catchments. For comparison, Venezuela's country-wide population density in 1960 (which included large, sparsely settled areas in the south) was 8.4 people $/ \mathrm{km}^{2}$ (as of 1997 it was 25/ $\mathrm{km}^{2}$ ). The lowest estimated population densities in 1960 of $0.1-0.5$ people $/ \mathrm{km}^{2}$ were found in the lowest elevation zone of the Bumbun and the upper zones of the
Canagua and Siniguis. An estimated $4-5$ people $/ \mathrm{km}^{2}$ occupied the 800- to $1400-\mathrm{m}$ zone on the Canagua and Siniguis as of 1960 , despite the fact that even today it is not possible to reach this area by vehicle.

The density of paved and secondary roads combined showed a trend similar to that of building density (Fig. 4). Values for the lowest elevation zone declined from a high of $0.3-0.4$ roads $/ \mathrm{km}$ in the Acarigua and Morador valleys to a low of $0.05-0.06$ roads $/ \mathrm{km}$ in the Siniguis and Bumbun valleys. The Acarigua catchment also had markedly more roads at higher elevation zones. Footpath density generally exceeded road density (Fig. 4, bottom) and did not conform to the general northeastern to southwestern gradient. The high footpath density in Canagua and Siniguis catchments reflected their access from the well-populated northern slopes of the high Andes and scattered habitations within the paramo region. In contrast, access to the upper reaches of Río Bumbun and Río La Yuca was more limited (personal observation).

Correlations among road density, building density, and percent disturbed land were positive but relatively weak when footpaths were excluded (building density and percent disturbed land, $R^{2}=0.30$; road density and percent disturbed land, $R^{2}=0.37$; building density and road density, $R^{2}=0.35$ ). When footpaths and roads were combined, the correlation with percent disturbed land was unaffected, but that between building density and road-plus-footpath density increased to $R^{2}=0.67$, indicating that footpaths are an important descriptor of access to an area.

Inspection of scatter plots revealed that correlations were weakened by the fact that the extent of disturbed land tended to be high relative to road and building density, throughout the 200- to 800-m elevation zone for most catchments. Accordingly, we reexamined the relationships, excluding the lowest elevation zone. This re-

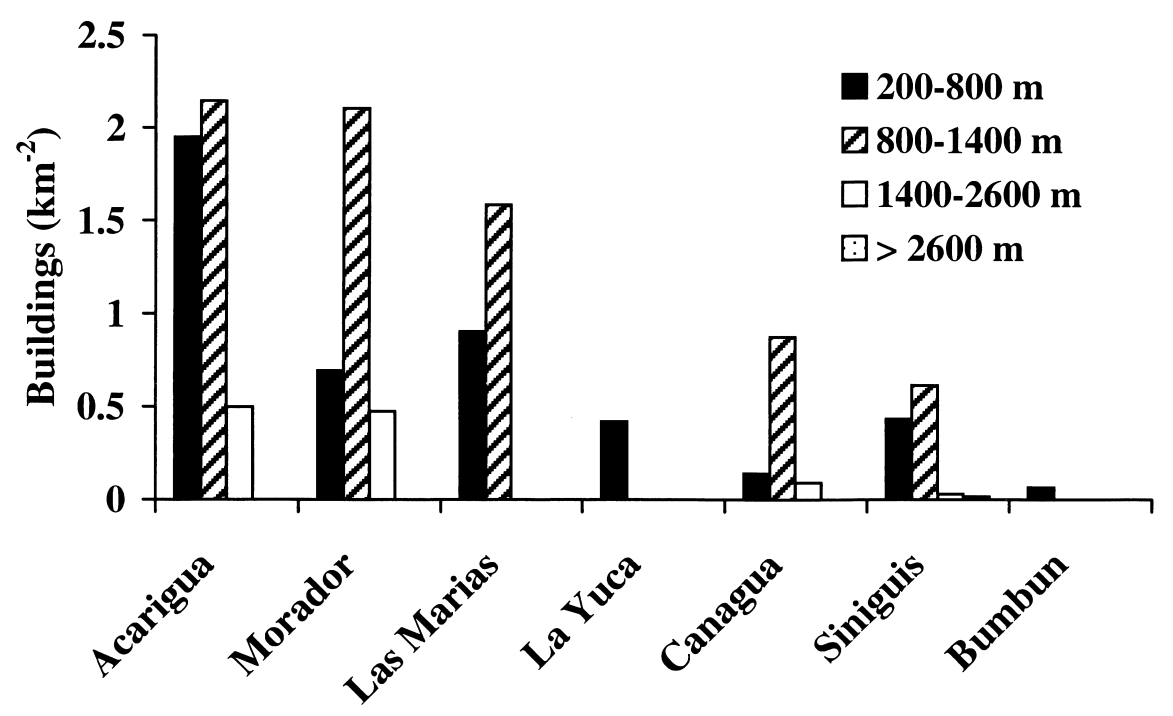

Figure 3. The number of buildings (bouses, schools, churches) in four elevation zones, for each of seven Andean catchments, expressed as numbers per square kilometer. Data are from 1:100,000 topographic maps and are based on aerial photographs from the 1960s. 

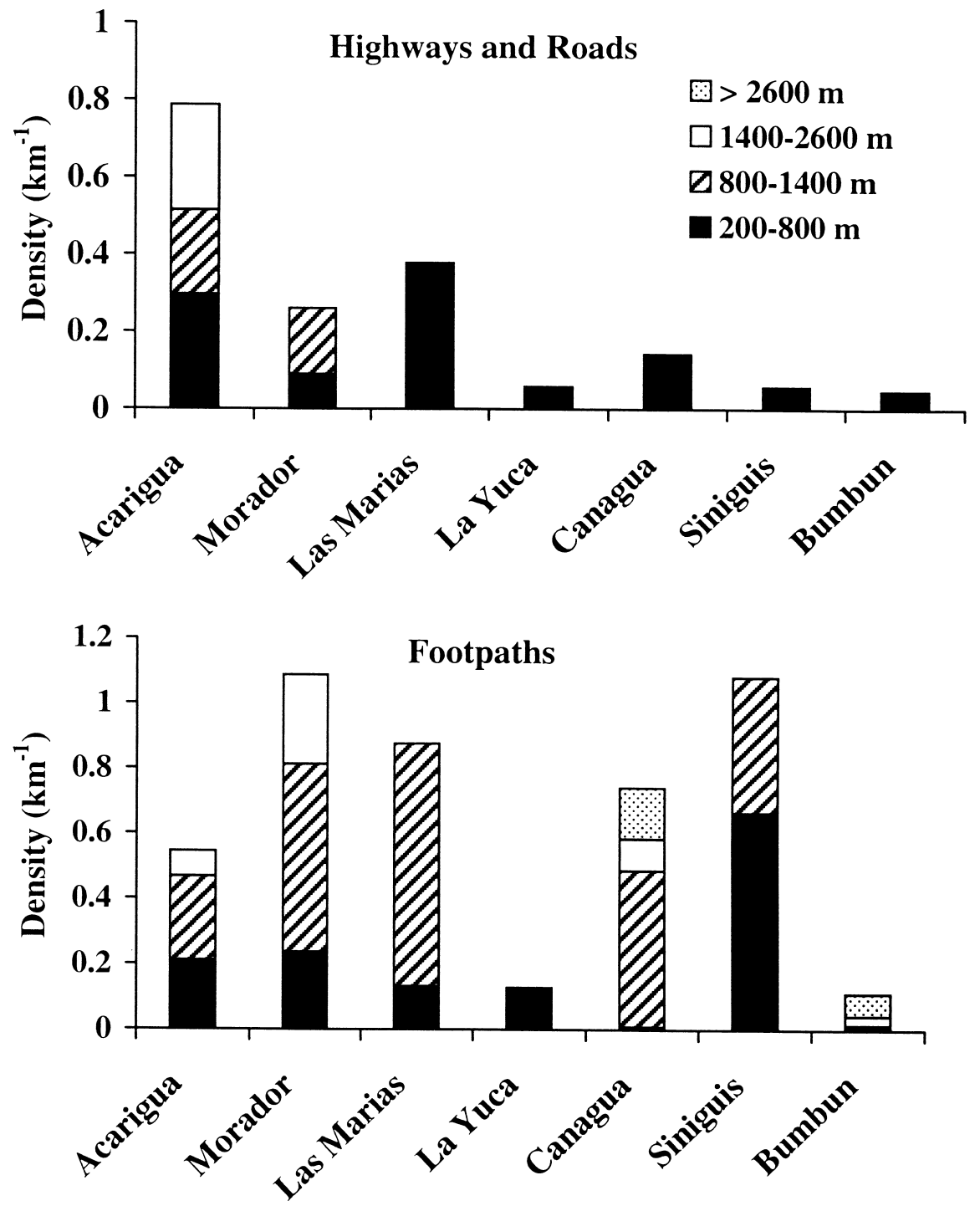

Figure 4. Density of paved and unpaved roads (upper panel) and footpaths (lower panel) in each of four elevation zones within seven Andean catchments per kilometer. Data are from 1:100,000 topographic maps and are based on aerial photographs from the 1960 s. sulted in much higher correlations between building density and road-plus-footpath density and between percent disturbed land and both road and building density (Fig. 5).

\section{Discussion}

Field observations of these seven catchments strongly indicated a gradient in human influence in a transect from northeast to southwest along the southern foothills of the Andes. Our analyses of land use support and extend these field observations. Total area of disturbed land declined, whereas area of forested land increased, from the Acarigua to the Bumbun catchments. Based on our land-use classification, this trend was less distinct in the lowest piedmont region (200-800 m) and most dramatic at middle elevations (800-1400 $\mathrm{m}$ and 1400$2600 \mathrm{~m}$ ) (Fig. 1). Measures of human occupation of these catchments varied in close accord with land use. We used 1960s building density as a surrogate for population density, because no exact population-density figures exist that can be related to catchment land area and subdivided by elevation zone. Although disturbance data are from 1996, whereas road- and building-density estimates are based on 1960s data, field observations indicated that road networks had changed little. Roads have improved in most of the catchments, however, and population density has unquestionably increased. Building and road densities correlated with each other and with the extent of disturbed land (Fig. 5). The 200- to 800-m zone of elevation generally had more disturbed land, relative to road and building density, than the upper elevation zones. Together, land use and settlement data point to a human disturbance gradient from the northeast to the southwest and from low to high elevations. In addition, within the lowest elevation zone, which had the greatest extent of disturbed land, forest cover increased away from roads (Fig. 2). 

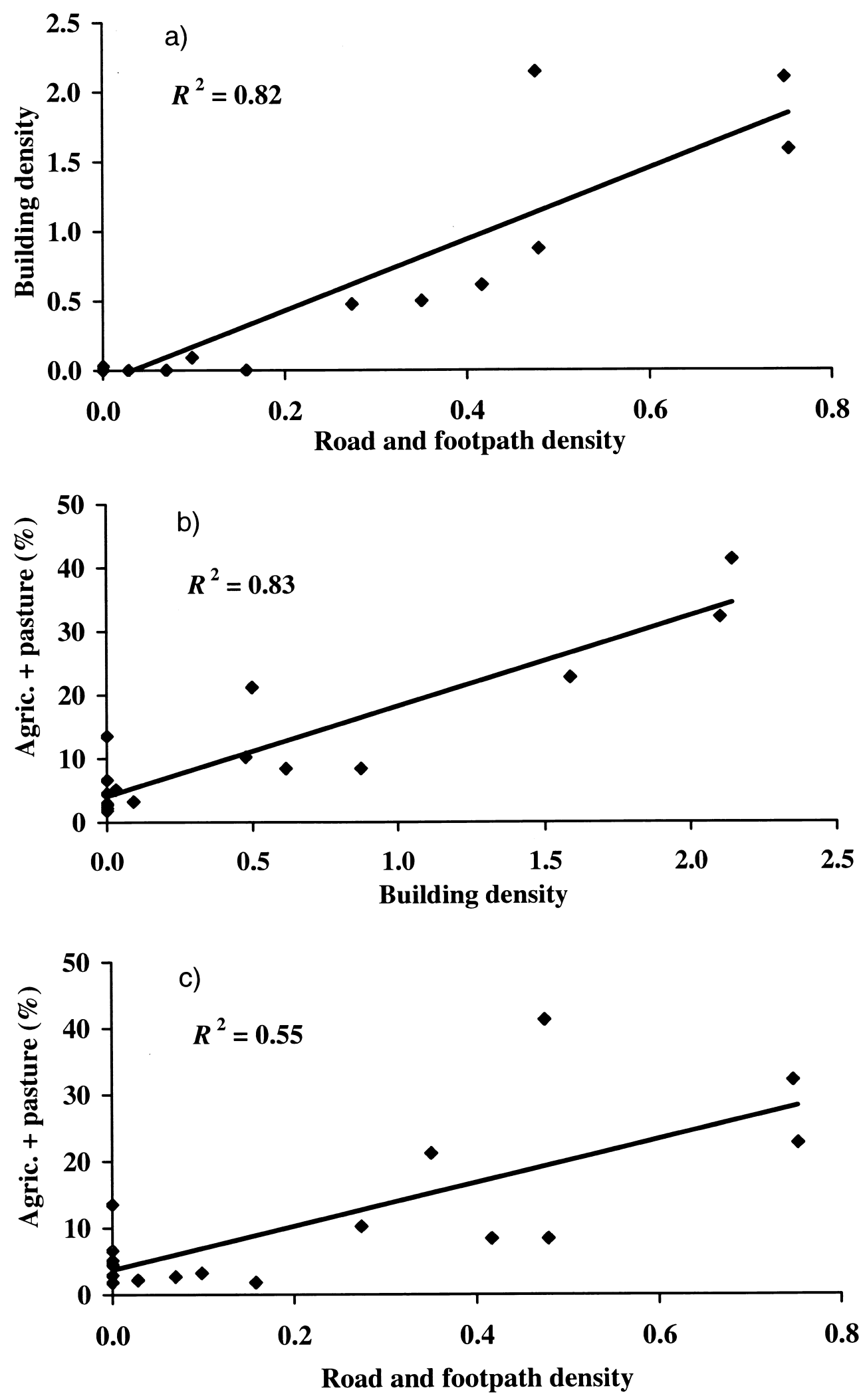

Figure 5. Relationships among buildings, roads, and extent of disturbed land, excluding the 200-to 800-m elevation zone, where extent of disturbance is disproportionately higher: (a) buildings versus roads and footpaths, (b) disturbed land versus building density, (c) disturbed land versus roads and footpaths. 


\section{Social and Land-Use History}

In attempting to interpret between-catchment differences in land use and likely social correlates, it is useful to include a brief overview of historical changes in this region. The Andean piedmont between Barinas and Socopo has shown evidence of indigenous populations since approximately 500 A.D. Archaeological evidence includes petroglyphs and regional networks of raised earthen causeways (calzadas), possibly constructed as an adaptive response to seasonal flooding (Spencer \& Redmond 1998). Drained-field farming is known from the period 550-1000 A.D. (Spencer et al. 1994). Most archaeological sites are in the llanos, although a few are located in the lower piedmont but below approximately the 300-m contour line.

European colonization of Venezuela's piedmont region lagged behind settlement of coastal areas and fertile highlands, but after 1550 settlements formed in the present-day cities of Acarigua, Guanare, and Barinas. Settlements and agriculture grew markedly during the seventeenth and eighteenth centuries, mainly at or below the elevation of the Llano Alto Highway. However, the boom in coffee after about 1830 likely contributed to the population spreading into higher lands. Price (1990) puts the "coffee zone" between 800 and $1500 \mathrm{~m}$, although today it can be found at both lower and higher elevations. Access to markets undoubtedly had considerable influence on the location and intensity of coffee growing (Fernandez et al. 1998). Of the study catchments, the Acarigua lies closest to the rail lines that link to Caribbean ports for coffee export. The watersheds southwest of Barinas were most remote from the major urban areas and railroads during the coffee era, and even in 1960 were not yet linked by paved highway.

Deforestation in this region clearly reflects recent change in addition to historical events. Between 1936 and 1950, the populations of Barinas and Portuguesa states grew by 42\% and 70\%, respectively. Between 1950 and 1961, these two states grew by $74 \%$ and $67 \%$ respectively, and the country grew by $49 \%$ over both time intervals. Although most population growth was in urban areas and along highways, market access for rural products must have grown substantially. But state-wide population statistics give only limited insight into changes in these rural catchments. Based on aerial photographs of selected sites in the lower piedmont, the Bumbun was roadless and forested in 1960 and showed evidence of a road and disturbed land in 1980, whereas the Río Las Marias, a much more altered site, was already substantially affected in 1960 (Karwan et al. 2001). The Siniguis and Canagua, in contrast, were settled by footpath much earlier and may have lost population during this time period (personal observation).

In sum, these watersheds share a complicated social and land-use history, involving an ebb and flow of settle- ment and types of land use, with particularly rapid change in the last half of the twentieth century. The result is substantial areas of disturbed land, which are greatest in extent near the major cities and transportation centers, at lower elevations, and near roads.

\section{Correlates of Land-Use Change}

Other studies document substantial deforestation during the latter part of the twentieth century. Tropical lowland forest in the Andean foothills of Colombia decreased from $72 \%$ to $33 \%$ coverage between 1938 and 1998, for a mean deforestation rate of $1.5 \%$ annually (Vina \& Cavelier 1999). They found that the rate was $<0.1 \%$ from 1938 to 1955 and as high as $4.4 \%$ from 1979 to 1988 . Obviously, episodes of deforestation can occur quite rapidly, especially at this spatial scale, but rates of deforestation also varied substantially from decade to decade in a country-wide analysis of deforestation in Costa Rica (Sader \& Joyce 1988). Accessibility, influenced by terrain but especially by roads, is clearly an important influence. In the northern Sierra de Los Tuxtlas region of southeast Mexico, Dirzo and Garcia (1990) observed that forest loss begins with clearing of low, flat areas and the opening of new roads, and proceeds upward to the least accessible areas.

An association between forest loss, road access, and population growth has been documented in several related studies. Similar to our findings, a study by Vina and Cavelier (1999), based on census data from a nearby town, found a strong pattern of population growth in an area of the Colombian Andes. Colonization and deforestation can be episodic, with periods of rapid land conversion followed by periods of relative stability. Both "push" factors, such as soil exhaustion that forces individuals to seek new lands and opportunities, and "pull" factors, such as development of road networks, influence the individual decisions that result in settlement and development (Rudel \& Horowitz 1993). Our results indicate that different processes may be operating in the 200- to 800-m zone than at higher elevations. In the lower piedmont, where large land-holdings were evident and roads allow access for field-workers and ready export of goods to markets, the extent of land disturbance was relatively high in relation to road and building density. In the upper elevations, where agricultural activities were at subsistence level or at least much smaller in scale (personal observation), local access and habitations were more closely associated with extent of disturbance (Fig. 5).

\section{Implications}

Tropical deforestation is well known for its negative effects on biodiversity (Whitmore \& Sayer 1992) and the global carbon budget (Houghton et al. 1983). Consequences for river ecosystems can also be serious. Forest 
loss increases water and sediment yield (Bruijnzeel \& Bremmer 1989) and can result in greater runoff from rain events, causing bank scouring, failure of bridges and roads, and habitat deterioration. The concentration of suspended sediments is roughly an order of magnitude greater in the Río Acarigua than in other, less-altered river valleys (J.D.A., unpublished data). A combination of aerial photography and satellite imagery (D. Karwan, unpublished data) indicates that the river channels changed shape between 1946 and the 1980s. The composition of invertebrate and fish assemblages also indicates substantial differences among these rivers and may reflect physical changes to river ecosystems for which land-use change is at least partly responsible (J.D.A., unpublished data). There is clearly a need for further research into the consequences of landscape change on rivers and biota in the tropical Andes.

\section{Acknowledgments}

We thank the University of Michigan Map Library for acquisition of imagery, the International Institute for financial support of image analysis, and The National Geographic Society and the H.R. Rackham School of Graduate Studies for support of field work. We appreciate the kindness of many local people, particularly the Figuero family, P. Caracas, and J. Raout. The manuscript benefited from the comments of several reviewers.

\section{Literature Cited}

Allan, J. D. 1995. Stream ecology. Kluwer Academic Publishers, Dordrecht, The Netherlands.

Baker, P., and W. Sanders. 1972. Demographic studies in anthropology. Annual Review of Anthropology 1:151-178.

Barbarino, A., D. C. Taphorn, and K. O. Winemiller. 1998. Ecology of the coporo, Prochilodus mariae (Characiformes, Procholodontidae), and status of annual migrations in western Venezuela. Environmental Biology of Fishes 53:33-46.

Bawa, J. S., and S. Dayanandan. 1997. Socioeconomic factors and tropical deforestation. Nature 386:562-563.

Bosch, J. M., and J. D. Hewlett. 1982. A review of catchment experiments to determine the effect of vegetation changes on water yield and evapotranspiration. Journal of Hydrology 55:3-23.

Bruijnzeel, L. A. 1989. (De)forestation and dry-season flow in the tropics: a closer look. Journal of Tropical Forest Science 1:229-243.

Bruijnzeel, L. A., with C. N. Bremmer. 1989. Highland-lowland interactions in the Ganges Brahmaputra River Basin: a review of published literature. Occasional paper 11. International Centre for Integrated Mountain Development, Kathmandu, Nepal.

Castillo, M. M., J. D. Allan, and S. Brunzell. 2000. Nutrient concentrations and discharges in a Midwestern agricultural catchment. Journal of Environmental Quality 29:1142-1151.

Dirzo, R., and M. C. Garcia. 1990. Rates of deforestation in Los Tuxtlas, a Neotropical area in southeast Mexico. Conservation Biology 6:84-90.

Fearnside, P. M. 1980. Land use allocation of the transamazon highway colonists of Brazil and its relation to human carrying capacity. Pages 114-138 in F. Barbira-Scazzochio, editor. Land, people, and planning in contemporary Amazonia. Occasional paper 3. Centre of Latin American Studies, University of Cambridge, Cambridge, United Kingdom.
Fernandez, L. E., J. Erazo, J. D. Allan, and A. J. Brenner. 1998. Investigating the role of transportation networks in land use change in the Venezuelan Andean piedmont: a historical and spatial analysis. III. Symposio internacional de desarollo sustenable de montañas: entendiendo las interfaces ecológicas para la gestión de los paisajes cultureales en los Andes. Quito, 9-14 December 1998. Corporación Editora Nacional, Quito, Ecuador.

Flecker, A. S. 1996. Ecosystem engineering by a dominant detritivore in a diverse tropical ecosystem. Ecology 77:1845-1854.

Gentry, A. H., and J. Lopez-Parodi. 1980. Deforestation and increased flooding of the Upper Amazon. Science 210:1354-1356.

Houghton, R. A., J. E. Hobbie, J. M. Melillo, B. Moore, B. J. Peterson, G. R. Shaver, and G. M. Woodwell. 1983. Changes in the carbon content of terrestrial biota and soils between 1860 and 1980: a net release of $\mathrm{CO}_{2}$ to the atmosphere. Ecological Monographs 53:235-262.

Johnson, L. B., C. Richards, G. E. Host, and J. W. Arthur. 1997. Landscape influences on water chemistry in Midwestern stream ecosystems. Freshwater Biology 37:193-208.

Karwan, D. L., J. D. Allan, and K. Bergen. 2001. Changing near-stream land use and river channel morphology in the Venezuelan Andes. Journal of the American Water Resources Association 37:15791588.

Lanly, J. P. 1995. The status of tropical forests. Pages 18-31 in A. E. Lugo and C. Lowe, editors. Tropical forests: management and ecology. Springer-Verlag, New York.

Melillo, J. M., C. A. Palm, R. A. Houghton, G. M. Woodwell, and N. Myers. 1985. A comparison of two recent estimates of disturbance in tropical forests. Environmental Conservation 12:37-40.

Nepstad, D. C., A. Verissimo, A. Alencar, C. Nobre, E. Lima, P. Lefebvre, P. Schlesinger, C. Potter, P. Moutinho, E. Mendoza, M. Cochrane, and V. Brooks. 1999. Large-scale impoverishment of Amazonian forests by logging and fire. Nature 398:505-508.

Omernik, J. M. 1977. Nonpoint source-stream nutrient level relationships: a nationwide study. EPA 600/3-77-105. U. S. Environmental Protection Agency, Corvallis, Oregon.

Poff, N. L., J. D. Allan, M. B. Bain, J. R. Karr, K. L. Prestegaard, B. D. Richter, and R. P. Sparks. 1997. The natural flow regime: a paradigm for river conservation. BioScience 47:769-84.

Price, M. D. 1990. Hands for the coffee: migration, settlement, and trade in western Venezuela, 1870-1930. Ph.D. dissertation. UMI Dissertation Services, Ann Arbor, Michigan.

Reaud-Thomas, G. 1989. Vegetation et utilisation du sol dans la region Guanare-Masparro, Andes Venezueliennes. Pages 137-201 in Venezuela, environment et changements. Number 63. Travaux et Documents de Géographie Tropicale, Centre d'Etudes en Géographie Tropicale-Centre de la Recherche Scientifique, Universitaire de Bordeaux, Talence, France.

Richards, C., L. B. Johnson, and G. E. Host. 1996. Landscape scale influences on stream habitats and biota. Canadian Journal of Fisheries and Aquatic Sciences 53(supplement 1):295-311.

Roth, N. E., J. D. Allan, and D. E. Erickson. 1996. Landscape influences on stream biotic integrity assessed at multiple spatial scales. Landscape Ecology 11:141-156.

Rudel, T., and B. Horowitz. 1993. Tropical deforestation: small farmers and land clearing in the Ecuadorian Amazon. Columbia University Press, New York.

Rudel, T., and J. Roper. 1996. Regional patterns and historical trends in tropical deforestation, 1976-1990: a qualitative comparative analysis. Ambio 25:160-166.

Sader, S. A., and T. Joyce. 1988. Deforestation rates and trends in Costa Rica. Biotropica 20:11-19.

Spencer, C. S., and E. M. Redmond. 1998. Prehispanic causeways and regional politics in the llanos of Barinas, Venezuela. Latin America Antiquity 9:95-110.

Spencer, C. S., E. M. Redmond, and M. Rinaldi. 1994. Drained fields at La Tigra, Venezuelan Llanos: a regional perspective. Latin America Antiquity 5:119-143. 
Vina, A., and J. Cavelier. 1999. Deforestation rates (1938-88) of tropical lowland forests on the Andean foothills of Colombia. Biotropica 31:16-31.

Whitmore, T. C. 1997. Tropical forest disturbance, disappearance, and species loss. Pages 3-12 in W. F. Laurance and J. R. O. Bierregaard, editors. Tropical forest remnants: ecology, management, and conservation of fragmented communities. University of Chicago Press, Chicago.
Whitmore, T. C., and J. A. Sayer. 1992. Deforestation and species extinction in tropical moist forests. Pages 1-14 in T. C. Whitmore and J. A. Sayer, editors. Tropical deforestation and species extinction. Chapman and Hall, London.

Winemiller, K. O., C. Marrero, and D. C. Taphorn. 1996. Perturbaciones causada por el hombre a las poblaciones de peces de los llanos y del piedmonte Andino de Venezuela. Biollania (Venezuela) 12:13-48.

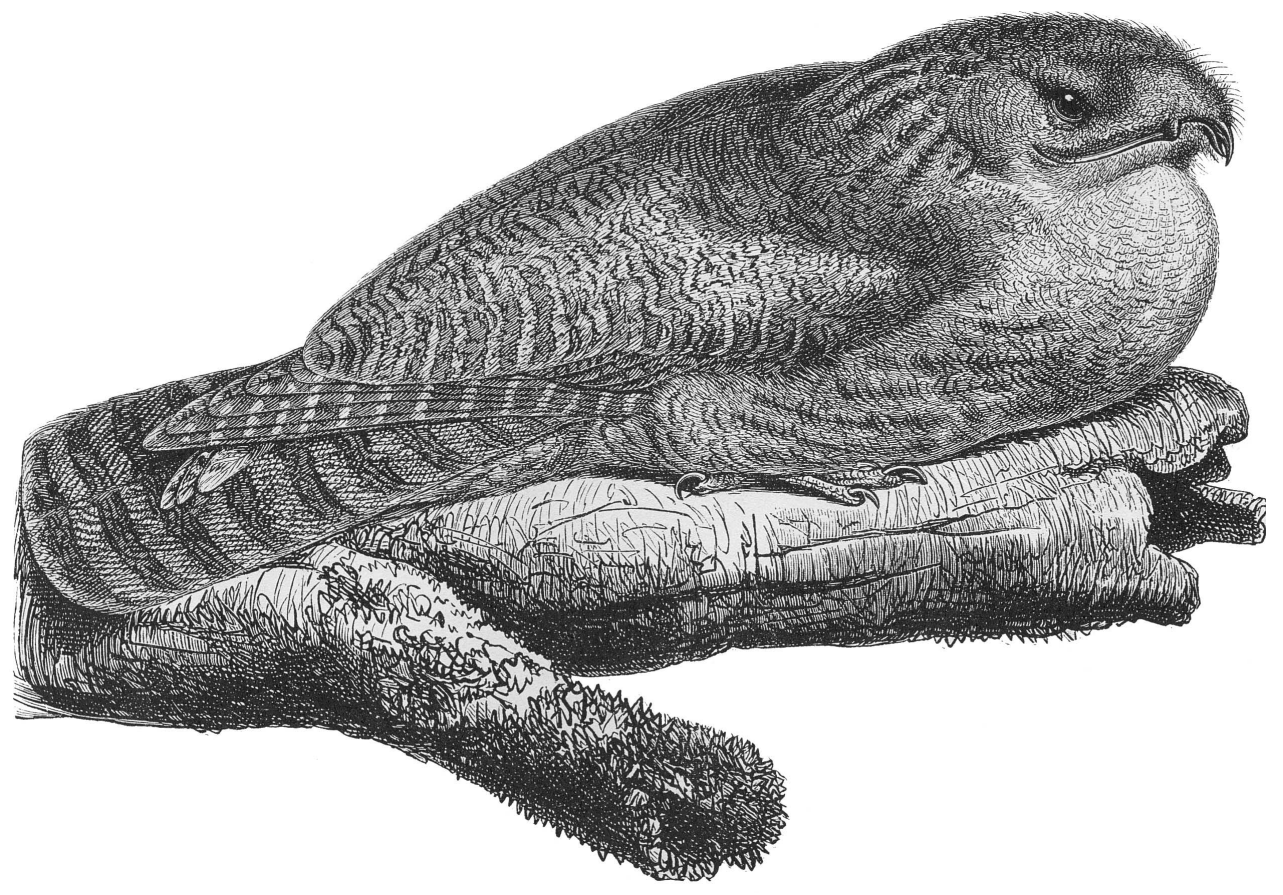

